\title{
Historical connections among river basins and climatic changes explain the biogeographic history of a water rat
} \\ 2 Departamento de Ciências Biológicas, Escola Superior de Agricultura "Luiz de Queiroz", Universidade de São Paulo, Piracicaba, São Paulo, Brazil \\ Corresponding Author: Jeronymo Dalapicolla \\ Email address: jdalapicolla@gmail.com
}

Background. The water rat Nectomys squamipes (Cricetidae: Sigmodontinae) is a semiaquatic rodent from eastern South America that shows shallow genetic structure across space, according to some studies. We tested the influence of hydrography and climatic changes on the genetic and phylogeographic structure of this semiaquatic small mammal.

Methods. DNA sequences of two mitochondrial genetic markers (Cyt b and D-loop) and six microsatellite loci from water rats were collected at 50 localities in five river basins in the Atlantic Forest along the eastern coast of South America. We evaluated the genetic structure within and among river basins, and we estimated divergence dates. Species distribution models for the present and past were built to identify possible gene flow paths.

Results. Mitochondrial data and species distribution models showed coherent results. Microsatellite loci showed a more complex pattern of genetic differentiation. The diversification of $N$. squamipes haplotypes occurred during the Pleistocene and the river basin cannot explain most of the genetic structure. We found evidence of population expansion during the last glacial maximum, and gene flow paths indicate historical connections among rivers in the Atlantic Forest.

Discussion. Historical connections among rivers in the Atlantic Forest may have allowed N. squamipes to disperse farther across and within basins, leading to shallow genetic structure. Population expansions and gene flow through the emerged continental shelf during glacial period support the Atlantis forest hypothesis, thus challenging the forest refuge hypothesis. 
1 Historical connections among river basins and climatic changes explain the

2 biogeographic history of a water rat

3 Jeronymo Dalapicolla ${ }^{1,2}$, Yuri Luiz Reis Leite ${ }^{1}$

4

$5 \quad{ }^{1}$ Departamento de Ciências Biológicas, Centro de Ciências Humanas e Naturais, Universidade

6 Federal do Espírito Santo, Vitória, Espírito Santo, Brazil.

72 Departamento de Ciências Biológicas, Escola Superior de Agricultura "Luiz de Queiroz",

8 Universidade de São Paulo, Piracicaba, São Paulo, Brazil.

9

10 Corresponding author:

11 Jeronymo Dalapicolla ${ }^{1,2}$

12 Email: jdalapicolla@gmail.com 
13 Abstract

14 Background. The water rat Nectomys squamipes (Cricetidae: Sigmodontinae) is a semiaquatic rodent from eastern South America that shows shallow genetic structure across space, according to some studies. We tested the influence of hydrography and climatic changes on the genetic and phylogeographic structure of this semiaquatic small mammal.

Methods. DNA sequences of two mitochondrial genetic markers (Cyt b and D-loop) and six microsatellite loci from water rats were collected at 50 localities in five river basins in the Atlantic Forest along the eastern coast of South America. We evaluated the genetic structure within and among river basins, and we estimated divergence dates. Species distribution models for the present and past were built to identify possible gene flow paths.

Results. Mitochondrial data and species distribution models showed coherent results.

Microsatellite loci showed a more complex pattern of genetic differentiation. The diversification of $N$. squamipes haplotypes occurred during the Pleistocene and the river basin cannot explain most of the genetic structure. We found evidence of population expansion during the last glacial maximum, and gene flow paths indicate historical connections among rivers in the Atlantic Forest.

Discussion. Historical connections among rivers in the Atlantic Forest may have allowed $N$. squamipes to disperse farther across and within basins, leading to a shallow genetic structure. Population expansions and gene flow through the emerged continental shelf during glacial period support the Atlantis forest hypothesis, thus challenging the forest refuge hypothesis. 


\section{Introduction}

In recent years, many phylogeographic studies have tested different hypotheses to explain the diversity and genetic structuring patterns found in vertebrates in the Atlantic Forest, eastern South America (Thomé et al., 2014). Quaternary climatic cycles have been considered the main drivers of population structure and genetic diversity but two opposing views regarding glacial periods emerged recently: population bottlenecks and stable refuges characterize the forest refuge hypothesis (FRH) (Carnaval \& Moritz, 2008), while population expansion onto the continental shelf is the main argument behind the Atlantis forest hypothesis (AFH) (Leite et al., 2016). The FRH is based upon forest retraction and fragmentation during glacial periods that would have caused isolation and consequently allopatric speciation within forest patches, or refuges, surrounded by open habitats (Haffer, 1969; Vanzolini \& Williams, 1970). Although originally formulated to account for species diversity in the Amazon, it was later adapted to explain high contemporary diversity and endemism at historically stable Atlantic Forest areas, or refuges (Carnaval \& Moritz, 2008; Valdez \& D’Elía, 2013). In this model, population size reductions are expected in unstable areas due to habitat loss during glacial periods and population stability or expansion during interglacials (Leite \& Rogers, 2013). The AFH, on the other hand, claims that forest specialist species actually expanded during the last glacial period (Last Glacial Maximum, LGM), following the expansion of the Atlantic Forest onto the emerged Brazilian continental shelf (Leite et al., 2016). Similarly to South-East Asia, where widespread rainforest covered the exposed Sunda shelf during the LGM (Wang et al., 2009; Raes et al., 2014), the marine regressions on the Brazilian coast exposed land where large stretches of rainforest would have flourished, leading to population expansion of forest species during glacial periods (Leite et al., 2016). 
The present study deals with the phylogeographic structure of a water rat, Nectomys squamipes (Brants), in the Atlantic Forest of eastern Brazil. The genetic structure of semiaquatic mammals may have been shaped differently from terrestrial mammals because the displacement through rivers may allow semiaquatic mammals to disperse further, leading to less genetic differentiation among populations (Centeno-Cuadros, Delibes \& Godoy, 2011). Consequently, the phylogeographic patterns would be more similar to those of large-sized mammals with great dispersal ability with shallow genetic structure. Alternatively, the specialisation to their habitat may constrain their dispersal patterns and, subsequently, the gene flow among populations, leading to a genetic phylogeographic structure that is more distinct that of other land mammals (Laurence, Smith \& Schulte-Hostedde, 2013).

In the Atlantic Forest, $N$. squamipes is adapted to semiaquatic life, living along river courses and having a broad geographic distribution, ranging from areas of Atlantic Forest to Cerrado (Bonvicino \& Weksler, 2015). This species has a small home range (0.7-3.96 ha), and the largest distance recorded between site of capture and a river course was approximately $520 \mathrm{~m}$ (Pires et al., 2002). Its displacements occur along riverbanks, and they are seldom farther than 7 m away from the margins (Lima, Pinho \& Fernandez, 2016). Therefore, high genetic divergence is expected among $N$. squamipes populations from different basins while individuals within the same basin should have low genetic divergence.

A study on N. squamipes nucleotide variation found a relevant genetic structure (Maroja, Almeida \& Seuánez, 2003), while two others found a shallow structuring among populations of a broader geographical area (Almeida et al., 2000a; 2005). Using randomly amplified polymorphic DNA (RAPD) (Almeida et al., 2000a) and microsatellites (Almeida et al., 2005), these authors 
78

concluded that the degree of genetic differentiation was low, contradicting the ecological data about the dispersal ability of $N$. squamipes.

Here we integrated analyses of mitochondrial and nuclear molecular markers with species distributions modelling to comprehend the phylogeographic structure of $N$. squamipes. Our goals were to: 1) evaluate evolutionary hypotheses to explain the biogeographic history of the water rat; 2) test if the genetic structure is strongly influenced by hydrography, leading to low gene flow and high divergence among basins, or if rivers allow $N$. squamipes to disperse across basins, leading to homogeneity and low genetic structure.

\section{Materials \& Methods}

Molecular data. We used 161 samples from 50 localities distributed throughout the range of $N$. squamipes (Figure 1). Two DNA sequence was obtained from GenBank (www.ncbi.nlm.nih.gov/genbank/), five were donated by researchers, and 154 liver and muscle samples preserved in ethanol were supplied by three mammal collections: CTA-UFES (Coleção de Tecidos Animais da Universidade Federal do Espírito Santo, Vitória, Brazil), MBML (Museu de Biologia Professor Mello Leitão, Santa Teresa, Brazil), and MCN-M (Museu de Ciências Naturais PUC Minas, Belo Horizonte, Brazil) (see Appendix S1 in Supporting Information). We sequenced $801 \mathrm{bp}$ of cytochrome $\mathrm{b}(\mathrm{Cyt} \mathrm{b}$ ) and $425 \mathrm{bp}$ from the control region of mitochondrial DNA (D-loop) (see Appendix S2, Table S2.1). The PCR products were purified with the enzymes ExoSAP (GE Healthcare Life Sciences, Little Chalfont, UK) and sequenced using Big

Dye 3.1 in the sequencer ABI 3500 (Applied Biosystems, Life Technologies Corporation, Waltham, USA). We carefully examined the electropherograms for both markers to check for noise and double peaks. We also had the Cyt $\mathrm{b}$ sequences aligned and translated to check for stop 
100

101

codons. Any sequences showing strong noise, double peaks or stop codons (for Cyt b) were discarded.

Sequences were used to obtain phylogenies through maximum parsimony (MP) in MEGA 5.2 (Tamura et al., 2011), Bayesian inference (BI) in MrBayes 3.2.2 (Ronquist et al., 2012), maximum likelihood (ML) in Garli 2.01 (https:/code.google.com/archive/p/garli/) and in PhyML 3.0 (Guindon \& Gascuel, 2003). The model of nucleotide substitution was selected using jModelTest 2.1.4 (Darriba et al., 2012) for Cyt b and D-loop individually. For the concatenated analysis, the data were partitioned, and the specific model was applied to each marker. Clade support was estimated through 100 bootstrap replications for MP and ML. The BI analysis was performed for $1.2 \times 10^{6}$ generations for Cyt b, $3 \times 10^{6}$ generations for D-loop, and $2.5 \times 10^{7}$ generations for the concatenated data, always with 2 runs with trees sampled every 1000 generations. We confirmed that effective sample sizes (ESSs) were above 200 in Tracer 1.6 (Rambaut et al., 2014) and then discarded the first $25 \%$ as burn-in. Nectomys rattus Pelzeln, Nectomys apicalis Peters, Amphinectomys savamis Malygin, Holochilus chacarius Thomas, Pseudoryzomys simplex (Winge), Oligoryzomys flavescens (Waterhouse), Oligoryzomys chacoensis (Myers \& Carleton) and Oligoryzomys nigripes (Olfers) were used as outgroups. Beast 1.8.2 (Drummond \& Rambaut, 2007) was used to date divergences among clades of Cyt b haplotypes, through 100 million generations using the lognormal relaxed clock and Yule process. Four secondary calibration points were defined based on studies that used multiple fossils for estimating clades ages within Sigmodontinae. The divergence between Pseudoryzomys and Holochilus at 2.58 million years ago (Ma) (0.43-5.38 Ma), and the divergence between Cerradomys and Sooretamys at 2.35 Ma(0.42-5.02 Ma), are from Machado et al. (2014), and the divergence among O. nigripes, O. flavescens, and O. chacoensis at 
123

124

125

3.71 $\pm 0.035 \mathrm{Ma}$ (Palma et al., 2010), and the divergence between Amphinectomys and Nectomys at 2.64 Ma (2.00-3.37 Ma) are from Leite, Kok \& Weksler (2015). The secondary calibrations priors were normally distributed, using the $95 \%$ confidence interval, following recommendations in Hipsley \& Müller (2014). A population dynamics plot (Bayesian skyline plot) was created using Cyt b sequences in Beast 1.8.2, covering 20 million generations and using the lognormal relaxed clock with the mutation rate found while dating the clades.

We grouped samples according to the river basins. Hydrographic boundaries followed the classification set by the Brazilian National Water Agency, using HidroWeb (http://hidroweb.ana.gov.br/) and GeoNetwork (http://metadados.ana.gov.br/geonetwork/srv/pt/main.home). We performed Bayesian Analysis of Population Structure (BAPS 6.0) (Corander et al., 2006) to estimate the number of genetic clusters present in each mitochondrial markers separately, and we compared them with our clusters based on river basin boundaries. We used a mixture model, clustering of linked molecular data, and tested $\mathrm{K}=1$ to 10 with 20 replicates per K. Haplotype networks were constructed in Network 4.6 (Bandelt, Forster, \& Röhl, 1999) using the median-joining tool and only sequences without ambiguities. Tests for neutrality (Tajima's D; $\mathrm{R}_{2}$; Fu's Fs), and genetic divergence $\left(\mathrm{F}_{\mathrm{ST}}\right)$ (Weir \& Cockerham, 1984) among clades, BAPS clusters, and river basins were performed in DnaSP 5.10 (Librado \& Rozas, 2009), and Arlequin 3.5 (Excoffier \& Lischer, 2010). The genetic distances within and among clades, BAPS clusters, and river basins were calculated in MEGA 5.2 (Tamura et al., 2011) using the p-distance.

We used six microsatellite loci as nuclear markers: Nec12, Nec14, Nec15, Nec18, (Almeida et al., 2000b), Nec19, and Nec23 (Maroja et al., 2003) (Table S2.1). The automated sequencer ABI 3500 was used for electrophoresis with size standard GeneScan 600 LIZ $^{\circledR}$ and 
146 allelic calling using GeneMapper 4.1 (Applied Biosystems, Life Technologies Corporation,

147 Waltham, USA). Allele sizes were corrected to avoid allelic drift using TANDEM 1.09

148 (Matschiner \& Salzburger, 2009). Our sample was divided into five groups representing the river

149 basins. Basic descriptive statistics, such as number of alleles, expected and observed

150 heterozygosity, gene diversity, and allelic richness were calculated for each locus and for each

151 river basin using GENEPOP 4.2 (Rousset, 2008), and FSTAT 2.9.3.2 (Goudet, 2001).

152 GENEPOP 4.2 was also used to test the linkage disequilibrium, null alelles frequency, and for 153 deviation from Hardy-Weinberg equilibrium (HWE) based on Fisher's method. $\mathrm{R}_{\mathrm{ST}}$ values were 154 calculated in Arlequin 3.5 (Excoffier \& Lischer, 2010) using 10,000 replications. expansions or bottlenecks within river basins using Two-Phased Model (TPM) and Stepwise Mutation Model (SSM). STRUCTURE 2.3.4 (Pritchard, Stephens \& Donnelly, 2000) was used to identify the genetic structure, with a priori classification by river basins using Locprior in admixture model, as suggested by Hubisz et al. (2009) and Pritchard et al. (2010), where the amount of available data is very limited (few markers or few individuals) or when the models do not provide indication of genetic structure. We used 100,000 burn-in steps followed by 300,000 Markov chain Monte Carlo (MCMC) simulation steps with 20 independent runs for each value of K (1-6). Structure Harvester (Earl \& von Holdt, 2012) was used for choosing the best number of assumed clusters $(\mathrm{K})$ based on the second order rate of change of the likelihood $(\Delta \mathrm{K})$ (Evanno, Regnaut, \& Goudet, 2005), and for evaluating the standard deviation of simulations for each K. CLUMPAK (Kopelman et al., 2015) was also used to produce the bar graphs for the 167 best $\mathrm{K}$. 
168

169

170

171

172

173

174

175

176

177

For all genetic markers we performed analysis of molecular variance (AMOVA), grouping our samples according to the river basins, and to localities inside the basins. Localities with only one sample were grouped with the nearest locality within the same river basin. We used only sequences without ambiguities, and genotyped samples with one missing locus at most. We conducted AMOVA in Arlequin 3.5 (Excoffier \& Lischer, 2010), using $F_{\mathrm{ST}}$ (mtDNA), and $\mathrm{R}_{\mathrm{ST}}$ (microsatellites) with 10,000 replications.

Species distribution modelling (SDM). We used MaxEnt 3.3.3k (Phillips, Anderson \& Schapire, 2006) and models were built using 30\% of the points for testing and the analysis was performed with the average model of 30 replications constructed through the bootstrap. The geographical area contemplated the five river basins in Brazil where the species is distributed: Paraná, São Francisco, South Atlantic (including Ribeira do Iguape river), Southeast Atlantic (including Doce and Paraíba do Sul rivers), and East Atlantic (including Jequitinhonha river). Since one of our goals was to infer palaeomodels, we used only 19 climate variables from Worldclim (Hijmans et al., 2005), which correspond to the variables available for the past. We modelled the present (1950-2000), the Last Glacial Maximum (LGM) ca. 22 ka, and the Last Interglacial (LIG) ca. 120-140 ka, all in 2.5 minutes resolution (approximately $5 \mathrm{~km}^{2}$ ). For the LGM, we used the MIROC-ESM model (Watanabe et al., 2011) and for the LIG we used the model by Otto-Bliesner et al. (2006).

A database with 463 georeferenced locations was compiled based on data from museums (242 points), scientific articles (95), theses and dissertations (126). The museum data were obtained from SpeciesLink (http://splink.cria.org.br/), Global Biodiversity Information Facility (GBIF - http://www.gbif.org), and Arctos Collaborative Collection Management Solution (http://arctos.database.museum/), or requested from curators. The points of occurrence were 
191

192

reviewed, and only data with precise specific locations were used. The locations of the points of occurrence were verified using Google Maps (http://maps.google.com.br), and two tools from SpeciesLink (http://splink.cria.org.br/) were used when compiling our locality database: 1) "geoLoc", which searches for place names in gazetteers, was used to georeference localities with no coordinates; 2) "infoXY", was used to fill out administrative data (country, state, county) for a given lat-long coordinate. The coordinates found in "geoLoc" were not used when building the models, only in the external validation test.

We selected only the most important variables indicated by the Principal Component Analysis (PCA) and those with correlation values less than 0.7 among them. Theses tests were perfomed in R 3.0.1 (R Foundation for Statistical Computing, Vienna, Austria) using "raster" (Hijmans \& van Etten, 2015) and "vegan" packages (Oksanen et al., 2015). Moreover, to reduce the spatial autocorrelation due to the sample bias, we used rarefy by environmental heterogeneity method using a $10 \mathrm{~km}$ buffer in SDMtoolbox 1.1c (Brown, 2014) in ArcGIS 10.1

(Environmental Systems Research Institute, Redlands, USA). Rarefy by environmental heterogeneity method was also used to reduce the spatial autocorrelation of the points in the external validation. This resulted in 109 occurrence points: 69 were used to create the SDM and 40 for external validation (see Table S2.2).

To estimate optimal model complexity for the SDM, we used "ENMeval" package in R 3.0.1 (Muscarella et al., 2014). We tested eight different feature class (FC) combinations (L, LQ, LQP, H, T, LQH, LQHP, LQHPT; where $\mathrm{L}=$ linear, $\mathrm{Q}=$ quadratic, $\mathrm{H}=$ hinge, $\mathrm{P}=$ product and $\mathrm{T}=$ threshold); with regularization values (RM) from 0.5 to 3.0 (increments of 0.5 ), and we used block method for partitioning occurrence data, which resulted in 48 individual model runs. The best model was one with minimum Akaike information criterion value (i.e. $\triangle \mathrm{AICc}=0$ ), $\mathrm{FC}=$ 
$214 \mathrm{LQH}$ and $\mathrm{RM}=2.0$. We evaluated this model with indices in MaxEnt validation and external 215 validation step. We analyzed the area under the curve (test AUC), default values and the p-value

216 for the three thresholds frequently used in MaxEnt: minimum training presence logistic

217 threshold, 10 percentile training presence logistic threshold, and maximum test sensitivity plus 218 specificity logistic threshold. Indices analyzed in the external validation were based on the $10 \%$ 219 threshold.

220 We built scatter plots for the three environmental variables that contributed most to the

SDM. The models were based on the $10 \%$ threshold and the environmentally appropriate area was calculated for each scenario (present, LGM and LIG) to evaluate whether there was variation in the size of the area over time.

Landscape genetics. The lists of haplotypes or alleles shared among localities, and LGM and present-day SDMs were used to create gene flow paths among sampling locations, indicating possible migration routes for $N$. squamipes. We modelled gene pathways under LGM because recovered gene flow may reflect older demographic connections. The most recent $\mathrm{Cyt} b$ population expansion may have taken place during the LGM as suggested by the Bayesian skyline plot (see Results below). The SDM was converted into a dispersal cost layer by inverting the model's suitability values (Chan, Brown, \& Yoder, 2011). Localities sharing haplotypes and alleles were connected by low cost paths using the dispersal cost map as a friction layer, in accordance with the method of Chan, Brown, \& Yoder, (2011). The software ArcGIS 10.1, and the package "arcpy" for Python v2.7.2 (Python Software Foundation, Delaware, USA) was used for these analyses.

\section{Results}


236 Molecular data. Of the 161 initial samples, 83 Cyt b sequences and 149 D-loop sequences of 237 Nectomys squamipes were obtained (77 and 148 sequences with no ambiguities, respectively); 238 sequences for both markers were obtained from 70 samples (Table S2.3). The difference in the

number of sequences obtained for the two genetic markers was largely due to double peaks and stop codons in the Cyt b sequences, possibly pseudogenes, which had been found in previous unpublished studies on N. squamipes (C. R. Bonvicino, National Cancer Institute of Brazil, pers. Comm., 2014). Five D-loop sequences were discarded due to double peaks. For microsatellites, 152 individuals were genotyped, representing 43 localities, 120 samples with one missing locus at most (Table S2.4). None of six loci had deviation from HWE in global tests, the average frequency of null alleles per locus was always below 0.14 (Table S2.5), and no linkage disequilibrium was observed for any pair of loci (Table S2.6).

The best evolutionary model for Cyt b sequences was HKY $+\mathrm{I}+\mathrm{G}$ and for D-loop was $\mathrm{HKY}+\mathrm{G}$. The trees with the best resolution and support $(>70 \%$ for $\mathrm{MP}$ and $\mathrm{ML}$, and $>95 \%$ for BI) were those from Cyt b sequences, recovering three main clades: North, Central and South, in reference to their latitudinal ranges, regardless of the optimality criteria used (Figure 2). The Central clade was not recovered in D-loop trees and in the BI tree with concatenated data; statistical support for these main clades were lower in D-loop and concatenated trees than Cyt b trees (see Appendix S3, Figure S3.1 for D-loop and concatenated trees). The differences in topologies are due to the absence of D-loop sequences of Nectomys apicalis and Amphinectomys savamis. When we removed these outgroup sequences from the Cyt b matrix, we recovered a Cyt b topology similar to D-loop and concatenated trees (Figure S3.2). Samples from the coast of São Paulo, which belong to the Southeast Atlantic basin, were phylogenetically associated with samples from Paraná and South Atlantic basins, indicating a phylogeographic break in 
259 mitochondrial DNA at Serra da Bocaina, a mountain range between the states of São Paulo and

260 Rio de Janeiro. The three main clades do not have a clear association with river basins. In

261 addition, haplotype networks of mitochondrial DNA (Cyt b and D-loop, Figure S3.3) showed

262 three groups, associated with the main clades from the phylogenetic trees (North, Central, and

263 South) but not with the river basins.

264 The three main clades of $N$. squamipes were also recovered in BAPS cluster analyses

265 (Figure 3). Cyt b data indicated 3 clusters, with the same composition of the three clades (Figure

3A). D-loop recovered 6 clusters, one corresponding to the North clade, one to the South clade

and 4 to the Central clade: Caparaó, North Doce River, South Doce River, and Southeast Atlantic cluster (Figure 3B).

Microsatellite data recovered four genetic clusters $(\mathrm{K}=4)$ for $N$. squamipes that are not related to the river basins (Figure 3C). These clusters were similar to the Cyt b clusters (Figure 3A) and clades (Figure 2), and are distributed across all basins, with different proportions depending on the locality (Figure 3C). Microsatellite samples from southern Brazil (Paraná, and South Atlantic) are homogeneous, forming one group, whereas those from the other three basins

(East Atlantic, São Francisco, Southeast Atlantic) are heterogeneous, showing different

probabilities of belonging to three distinct groups, which are unrelated to the basins (Figure 3C), but somewhat compatible with mitochondrial DNA clades (Figure 2; Figure S3.1).

Haplotype networks of mitochondrial DNA showed few mutational steps among groups

(Cyt b and D-loop, Figure S3.3), indicating low genetic divergence within N. squamipes. Genetic distances also showed similar results, small divergence within and among the $N$. squamipes clades, BAPS clusters, and river basins for Cyt b, and higher values for D-loop (Table S2.7). Nectomys squamipes has low intraspecific divergence (1.3\% Cyt b; $2.7 \%$ D-loop), and the three 
282 intraspecific clades also display small genetic distances, with little intraclade $(0.5-0.8 \%$ Cyt b;

283 1.5-1.7\% D-loop) and interclade divergences for Cyt b (1.8-1.9\%); interclade divergences for D-

284 loop were higher (4.0-4.9\%). In addition, samples from the São Francisco basin have greater

285 intraregional diversity $(1.6 \% \mathrm{Cyt} b ; 3.9 \%$ D-loop $)$ than those from the other basins $(0.1-1.2 \%$

286 Cyt b; 0.5-2.2\% D-loop). The most recent common ancestor of all Cyt $\mathrm{b}$ haplotypes from

287 Nectomys spp. dates back to the Plio-Pleistocene period 2.7-1.3 Ma, and Cyt b haplotypes from

288 N. squamipes diverged 1.64-0.51 Ma (Figure 4). The three clades found in N. squamipes

289 separated 1,160,000-198,000 years ago in the Pleistocene (see Table S2.8). The mutation rate

290 was estimated at 0.028 mutation/site/million years.

No significant values were found for most neutrality tests (Table S2.9). Samples from the

292

293

294

295

296

297

298

299

300

301

302

303

304

Southeast Atlantic basin and the Central clade showed significant values in both markers.

Significant values were also found for the Central (Cyt b) and Southeast Atlantic (D-loop)

clusters in BAPS. These significant values indicate population expansions in the central area of the N. squamipes distribution. However, the effective population size estimated using microsatellite data indicated stability in the Southeast Atlantic basin and for $N$. squamipes as a whole (Table S2.10). These data also indicated population expansion in the Paraná basin and a recent bottleneck in the East Atlantic basin. Sample sizes were too small for estimating demographic histories of the São Francisco and the South Atlantic basins. Bayesian skyline plot showed continuous growth between the LIG and the LGM (120,000-20,000 years ago) for $N$. squamipes, and a decline toward the present, despite a wide confidence interval (Figure 5).

We found different levels of population differentiation among river basins depending on the marker, and the river basin analysed (Table S2.11). The highest $\mathrm{F}_{\mathrm{ST}} / \mathrm{R}_{\mathrm{ST}}$ values were found in comparisons including the South Atlantic basin in all markers $(\mathrm{Cyt} b=0.36-0.56$; D-loop $=$ 
305 306

0.19-0.39; Microsatellite $=0.09-0.13)$. Other river basins presented moderate values for $\mathrm{F}_{\mathrm{ST}} /$ $\mathrm{R}_{\mathrm{ST}}(\mathrm{Cyt} \mathrm{b}=0.16-0.28 ; \mathrm{D}-$ loop $=0.05-0.20 ;$ Microsatellite $=0.01-0.05)$. Among the genetic markers, Cyt $b$ showed the highest values of population differentiation $\left(\mathrm{F}_{\mathrm{ST}}=0.16-0.56\right)$, while the microsatellite showed the lowest values $\left(\mathrm{R}_{\mathrm{ST}}=0.01-0.13\right)$. River basins explain only $11.08 \%$ of the genetic variation found in Cyt b, and were irrelevant for D-loop and microsatellite loci (Table 1). In addition, most of the genetic variation is within localities.

Species distribution modelling. The SDM showed good statistical indices in the validation step (Table S2.12). The mean diurnal range of temperature (Bio 02) was the variable that contributed most to the model $(62.02 \%)$, followed by the precipitation of warmest quarter (Bio 18: 20.39\%), and the precipitation of wettest month (Bio 13: 14.42\%) (Figure S3.4).

Areas with the highest suitability for the occurrence of $N$. squamipes in the present run almost continuously along the coast (Figure 6A). The surface area suitable for $N$. squamipes in the present is $1,270,920.73 \mathrm{~km}^{2}$ (considering the $10 \%$ threshold). The projection for the LGM shows a $62 \%$ increment $\left(2,053,436.92 \mathrm{~km}^{2}\right)$, with the most suitable areas on the coast and inland near the headwaters of the São Francisco river, on the Espinhaço range, and along the Paraná river (Figure 6B). The coast was displaced to the east during the LGM, exposing the continental shelf, which has areas of high environmental suitability for $N$. squamipes. Such areas run almost continuously from north to south, with a marked break at Serra da Bocaina, an area that shows lower suitability in the present as well (Figure 6A). The LIG model indicated a sharp reduction in the suitable area for the species $\left(620,808.98 \mathrm{~km}^{2}\right)$, a $51 \%$ decrease compared to the present, and a $70 \%$ decrease from the LGM. Highly suitable areas are restricted to the coast, with a break between Bahia and Rio de Janeiro (Figure 6C). Therefore, we detected three major suitable areas in the LIG: two larger areas, one in the south and the other in northeast Brazil, and a third area 
328 around Rio de Janeiro in southeast Brazil. These three areas were also recovered in the LGM and 329 in the present-day (Figure 6A-B), and they are similar to the geographical location of the three 330 clades in the mitochondrial DNA analysis (Figure 2).

331 Landscape genetics. Cyt b and microsatellite flow paths indicated gene flow between distinct 332 river basins, but D-loop paths pointed to more gene flow within river basin, regardless of

temporal scale (Figure 7). The microsatellite flow maps (Figure 7C and 7F) is very similar to the Cyt b maps (Figure 7A and 7D), and they are both distinct from the D-loop maps (Figure 7B and 7E). The main difference between Cyt $\mathrm{b}$ and microsatellites is the presence of gene flow extending further south in the latter (Figure 7C and 7F). The dispersal cost maps were created using only climatic variables, but the paths coincided with some main rivers in the Atlantic Forest. Four main paths among river basins were identified (Figure 7): 1) along the coast between Paraíba do Sul and Jequitinhonha rivers (and Tietê for microsatellite data), connecting the East Atlantic and Southeast Atlantic basins (and South Atlantic basin for microssatellites); 2) along the Doce River and its tributaries, connecting the Southeast Atlantic basin to the others; 3) along the Tietê River and its tributaries, connecting the Paraná, South Atlantic and the Southeast Atlantic basins; and 4) along the Preto River connecting the Grande River sub-basin, which belongs to the Paraná River basin and Southeast Atlantic basin. Gene flow maps from the LGM showed differences in the use of the exposed continental shelf depending on the molecular marker: Cyt b (Figura 7A) and microsatellites (Figure 7C) showed that highest probabilities for gene flow paths are within the continental shelf, but not D-loop (Figure 7B).

\section{Discussion}

Genetic structure and historical connections among river basins. Our results showed a shallow genetic structure in $N$. squamipes, and mitochondrial DNA and microsatellite clusters 
351 are not strongly related to the five river basins. All molecular markers showed a latitudinal

352 genetic structure of the water rat, with three clades: north, central and south, with SDMs for

353 354 different temporal scales recovering suitable areas in the same geographical location of these three clades.

The only results indicating strong genetic structure by river basin were $\mathrm{F}_{\mathrm{ST}}$ values for mitochondrial markers, which may be due to its matrilineal history and smaller effective population size when compared with microsatellite markers (Avise, 2000). Indeed, female $N$. squamipes have smaller home ranges and move less than males (Lima, Pinho \& Fernandez, 2016), which may indicate that they are philopatric to natal sites. The small number of microsatellite loci used and their capability of detecting the true population structure is another plausible explanation for the discrepancy between this marker and mtDNA. Other recent studies using a similar number of microsatellite markers in other organisms (Pérez-Alquicira et al., 2018; Villamor et al., 2018; Zheng et al., 2018) also found significant genetic structure in some cases. Another study using the same microsatellite loci (Maroja, Almeida \& Seuánez, 2003) found significant genetic differentiation in N. squamipes samples from a very small geographic area (maximum distance among sites $=6 \mathrm{~km}$ ). We therefore believe that the number of microsatellites loci were adequate infer the genetic structure in our dataset.

The phylogeographic break at Serra da Bocaina is concordant with the boundaries of two freshwater ecoregions, Ribeira do Iguape and Paraíba do Sul, delimited by the Freshwater Ecoregions of the World (FEOW) system provided by Abell et al. (2008). This is, however, the only break matching the FEOW, and the three clades do not follow the FEOW divisions. More samples, especially from the state of Rio de Janeiro, are needed to better delimit this phylogeographic break at Serra da Bocaina. 
We considered the genetic structure of mitochondrial data is relatively shallow because

375

376

377

378

379

380

381

382

383

384

385

386

387

388

389

390

391

392

393

394

395

396

there are: (i) few statistically supported clades; (ii) clades with short branches in the phylogenetic trees; and (iii) few isolated haplotypes in the haplotype networks. These same factors were found in the small semiaquatic rodent, Arvicola sapidus Miller (Centeno-Cuadros, Delibes \& Godoy, 2009). In addition, the $N$. squamipes clades are separated by small genetic distances, which confirm low degree of differentiation (Almeida et al., 2005). Genetic studies on some small semiaquatic rodents, such as the muskrat Ondatra zibethicus (Linnaeus) (Laurence, Smith \& Schulte-Hostedde, 2013) corroborated the shallow genetic structure and low divergence observed when the opposite was expected. Large semiaquatic mammals, such as beavers (Castor fiber Linnaeus) and otters [Lutra lutra (Linnaeus)], also display a shallow genetic structuring among populations in different river basins (Durka et al., 2005; Quaglietta et al., 2013). These cases may be explained by their greater dispersal ability as a function of body size and by the hunting pressure that led to a bottleneck effect (Durka et al., 2005; Quaglietta et al., 2013). Even for populations of the largest rodent, the capybaras [Hydrochoerus hydrochaeris (Linnaeus)], the importance of river basins is variable according to river system (Byrne et al., 2015). These results indicate that the dependency on rivers could favour the displacement of semiaquatic mammals and, as a consequence, gene flow, resulting in low divergence and shallow genetic structure. For instance, muskrats have an opportunistic behavior in the use of terrestrial landscape and population structure was not influenced by watershed network or landscape composition, and landscape features had a limited effect on gene flow (Laurence, Smith \& Schulte-Hostedde, 2013). Some specialist species may be considered generalist in their use of the landscape for dispersal, such as the southern water vole (Centeno-Cuadros, Delibes \& Godoy, 2011), which uses several landscape types during dispersal, increasing gene flow. There is no 
397 landscape use data available for $N$. squamipes during dispersal but there are records that this

398 species is capable of moving by land between forest fragments in the Atlantic forest during the 399 dry season (Pires et al., 2002; Lima, Pinho \& Fernandez, 2016), and the genetic structure we 400 found suggests a more generalist behaviour during dispersal events, allowing individuals to 401 move between basins.

402 There has been a recent population expansion in the Southeast Atlantic and Central 403 clade/cluster according to the neutrality tests. Moreover, there are haplotypes in the Southeast 404 405 place now or in the recent past because the shared haplotypes concentrate at the borders. The microsatellite data, on the other hand, suggest stability rather than expansion in the Atlantic Southeast. This incongruence might be the result of the distinct temporal scales documented by these markers. Mitochondrial loci reflect older events than microsatellite loci (Putman \& Carbone, 2014) and, in this context, the expansion detected by Cyt b and D-loop happened earlier than the recent populations stabilization documented by microsatellites. The same argument is valid for the differences between neutrality tests for the species as a whole, which indicated expansion of effective mitochondrial population size and stability based on microsatellite data. Moreover, SDMs showed that there is an increase of suitable areas in the Southeast Atlantic region from LIG to LGM, supporting the possibility of population expansion. The gene flow paths among different basins occur at specific areas. The watersheds at the headwaters of rivers that delimit a basin may facilitate the connection among basins due to tectonic activity or erosion (Ribeiro, 2006). Important tectonic activity in the past 1.6 million years in the Atlantic Forest region may have caused reorganisation of river basins due to the capture of the headwaters of other rivers (Saadi et al., 2002). This phenomenon may affect both 
420 the migration of species among rivers and the current aquatic and semiaquatic organism

421 communities. The shared fish fauna between river basins documented by several authors may

422 indicate connection between them during the Quaternary (Ribeiro, 2006), which is the

423 diversification period of $N$. squamipes. For example, Pereira et al. (2013) found phylogeographic

424 structure in an Atlantic forest trahira Hoplias malabaricus (Bloch) nearly identical to presented

425 here for $N$. squamipes. They explained this structure by recent dispersal events congruent with

426 historical connections among river basins caused by sea level variations and stream piracy. The

427 same factors may also explain the connections among river basins found here for $N$. squamipes

428 populations (for details, see Figure S3.5).

Responses to past climate changes. Temperature is an important factor in the geographic distribution of $N$. squamipes, lower mean diurnal range of temperature (Bio 02) was the most important variable for constructing the distribution models. This variable is directly related to the biology of this water rat because it lives near water bodies where the temperature is more stable during the day, and therefore coastal areas with narrow temperature range are highly suitable in the SDM. Population fluctuations over the past 120,000 years followed the temperature variations documented by the stable isotope oxygen-18 $\left(\delta^{18} \mathrm{O}\right)$ (Cohen \& Gibbard, 2012), with an expansion in the LGM, but the confidence interval is quite wide. We also found evidence of population expansion in the neutrality tests, and the expansion of suitable areas through time is consistent with an expansion in the LGM when the climate was cooler. The evidence of population and range expansion in the LGM and contraction of suitable areas with increasing temperature both in the present and in the LIG contradict the forest refuge hypothesis to explain the biogeographic history of this species. The phylogeography of $N$. squamipes documented here fits the Atlantis forest hypothesis, which predicts the expansion of Atlantic forest onto the 
443 continental shelf during the LGM. This is in accordance with our estimate of population sizes, 444 our species distribution model for the LGM, as well as coastal gene flow pathways displaced to 445 the now submerged continental shelf. D-loop was the only genetic marker that did not show gene 446 flow paths on the continental shelf during the LGM. The rate of evolution in D-loop sequences is

intermediate between the slower Cyt $\mathrm{b}$ and the faster microsatellites, therefore D-loop flow paths probably result from distinct events that took place in an intermediate time, such as an interglacial period, when dispersal was restricted.

Nectomys squamipes populations may have been favoured during glacial periods despite possible decrease in plant cover and increase in rainfall seasonality (Behling, 2002; Carnaval \& Moritz, 2008). This scenario may have reduced the habitat of other semiaquatic mammal because of lower river level, while favouring $N$. squamipes, a more generalist species that prefers small marshy streams over larger rivers with faster-running water (Lima, Pinho \& Fernandez, 2016). Another factor that may have contributed to an increase in the distribution of $N$. squamipes during the LGM is the decrease in ocean levels, which were on average $68 \mathrm{~m}$ lower than their current level (Lambeck, Esat, \& Potter, 2002; Rabineau et al., 2006). This increased not only the land surface, but also extended the course of rivers flowing into the Atlantic Ocean (Weitzman, Menezes, \& Weitzman, 1988; Clapperton, 1993; Thomaz et al., 2015), allowing connections that are now hidden by the ocean, and favouring dispersal and gene flow during this glacial period. When the sea rose to its current level, coastal populations were isolated in the higher areas that became oceanic islands, which is in agreement with the current genetic structure of island populations of $N$. squamipes (Almeida et al., 2005). Therefore, riparian forests may have functioned as corridors among forest fragments because they have the same resource availability (Naxara, 2008). Pleistocene palaeodrainages were crucial in structuring genetic diversity in fish 
466 (Thomaz et al., 2015), and these palaeodrainages may have played an important role shaping the genetic structure of $N$. squamipes as well.

Dating revealed a Pleistocene origin for the Cyt b haplotypes of $N$. squamipes and for the three main clades. This result indicates that climate oscillations in the period may have been important both for the speciation of the genus and for the genetic structuring of $N$. squamipes. The three main geographic regions resulting from modelling the LIG are similar to the clades found in the phylogenetic trees, indicating correspondence between the modelled ecology data and the genetic data, as described in other studies (Igea et al., 2013). Taking into account that there were several glacial periods during the Pleistocene, with interglacial periods in between, the $N$. squamipes populations may have undergone recurring processes of population reduction and expansion (Almeida et al., 2000a).

\section{Conclusions}

Our results showed a shallow genetic structure in the water rat, slightly influenced by river basins. The pattern of genetic diversity is best explained by latitude with three main clades structured from north to south. There is evidence of recent population and suitable area expansions during glacial period for $N$. squamipes. The presence of suitable areas and gene flow paths through the continental shelf, and population expansions during the glacial period, give support to the Atlantis forest hypothesis. Rivers and historical connections between rivers allowed $N$. squamipes to disperse farther across and inside basins, leading to a shallow genetic structure.

\section{Acknowledgments}

C. R. Bonvicino, L. P. Costa, M. A. Sábato, M. Lara, M. Passamani, R. Moura, V. Fagundes and the collections of the Museu de Biologia Professor Mello Leitão (MBML), Museu 
de Ciências Naturais da PUC-Minas (MCMN) and Universidade Federal do Espírito Santo

(UFES), which all donated tissue samples for this study. K. P. M. B. Ferraz, M. C. Ribeiro, F. C.

Barreto and J. P. Hoppe provided great help with the distribution modelling, T. E. Simon (in memorian) and J. F. Justino with microsatellite analysis, H. Seibel Jr. with Python scripts, K. A. Boher with BAPS analysis. A. B. Santos, V. Fagundes, A. Percequillo, A. T. Thomaz, A. C. Loss, and anonymous reviewers made suggestions that improved the quality of earlier drafts of this manuscript.

\section{Supporting Information}

Additional Supporting Information may be found in the online version of this article.

Appendix S1: List of genetic samples of Nectomys.

Appendix S2: Amplification profiles, locality data, GenBank accession numbers, microsatellite data, genetic distances, divergence dates, neutrality tests; heterozigote rates for microsatellite data, $\mathrm{F}_{\mathrm{ST}} / \mathrm{R}_{\mathrm{ST}}$ values, and validation indices.

Appendix S3: Phylogenies for Cyt b, D-loop, and concatenated data; haplotype networks; main SDM variables; historical connections.

\section{References}

Abell R, Thieme ML, Revenga C, Bryer M, Kottelat M, Bogutskaya N, Coad B, Mandrak N, Balderas SC, Bussing W, Stiassny MLJ, Skelton P, Allen GR, Unmack P, Naseka A, Ng R, Sindorf N, Robertson J, Armijo E, Higgins J V., Heibel TJ, Wikramanayake E, Olson D, López HL, Reis RE, Lundberg JG, Pérez MHS, Petry P. 2008. Freshwater Ecoregions of the World: A New Map of Biogeographic Units for Freshwater Biodiversity Conservation. BioScience 58: 403-414. DOI: 10.1641/B580507.

Almeida FC, Maroja LS, Moreira MAM, Seuánez HN, Cerqueira R. 2005. Population 
512 structure and genetic variability of mainland and insular populations Nectomys squamipes

513 (Rodentia, Sigmodontinae). Genetics and Molecular Biology 28: 693-699. DOI: 10.1590/S1415-

$514 \quad 47572005000500008$.

515 Almeida FC, Moreira MAM, Bonvicino CR, Cerqueira R. 2000a. RAPD analysis of 516 Nectomys squamipes (Rodentia, Sigmodontinae) populations. Genetics and Molecular Biology 517 23: 793-797. DOI: 10.1590/S1415-47572000000400014.

518 Almeida FC, Maroja LS, Seuánez HN, Cerqueira R, Moreira MAM. 2000b. Identification 519 of microsatellite loci in the water-rat Nectomys squamipes (Rodentia, Sigmodontinae). Molecular 520

Ecology 9: 2172-2173. DOI: 10.1046/j.1365-294X.2000.105310.x

Avise J. 2000. Phylogeography: the history and formation of species. Cambridge: Harvard University Press.

Bandelt HJ, Forster P, Röhl A. 1999. Median-Joining networks for inferring intraspecific phylogenies. Molecular Biology and Evolution 16: 37-48. DOI:

10.1093/oxfordjournals.molbev.a026036.

Behling H. 2002. South and southeast Brazilian grasslands during Late Quaternary times: a synthesis. Palaeogeography, Palaeoclimatology, Palaeoecology 177: 19-27. DOI:

10.1016/S0031-0182(01)00349-2.

Bonvicino CR, Weksler M. 2015. Genus Nectomys Peters, 1861. In: Patton JL, Pardiñas UFJ, D’Elía G, eds. Mammals of South America, Volume 2. Chicago and London: The University of Chicago Press, 369-377.

Brown JL. 2014. SDMtoolbox: a python-based GIS toolkit for landscape genetic, biogeographic and species distribution model analyses. Methods in Ecology and Evolution 5: 694-700. DOI: 10.1111/2041-210X.12200. 
535

536

537

538

539

540

541

542

543

544

545

546

547

548

549

550

551

552

553

554

555

556

557

Byrne MS, Quintana RD, Bolkovic ML, Cassini MH, Túnez JI. 2015. The role of river drainages in shaping the genetic structure of capybara populations. Genetica 143: 645-656. DOI: 10.1007/s10709-015-9862-1.

Carnaval AC, Moritz C. 2008. Historical climate modelling predicts patterns of current biodiversity in the Brazilian Atlantic forest. Journal of Biogeography 35: 1187-1201. DOI: 10.1111/j.1365-2699.2007.01870.x.

Centeno-Cuadros A, Delibes M, Godoy JA. 2009. Phylogeography of Southern Water Vole (Arvicola sapidus): evidence for refugia within the Iberian glacial refugium? Molecular Ecology 18: 3652-3667. DOI: 10.1111/j.1365-294X.2009.04297.x.

Centeno-Cuadros A, Román J, Delibes M, Godoy JA. 2011. Prisoners in their habitat?

Generalist dispersal by habitat specialists: a case study in southern water vole (Arvicola sapidus).

PloS one 6: e24613. DOI: 10.1371/journal.pone.0024613.

Chan LM, Brown JL, Yoder AD. 2011. Integrating statistical genetic and geospatial methods brings new power to phylogeography. Molecular Phylogenetics and Evolution 59: 523537. DOI: 10.1016/j.ympev.2011.01.020.

Clapperton CM. 1993. Nature of environmental changes in South America at the Last Glacial Maximum. Palaeogeography, Palaeoclimatology, Palaeoecology 101: 189-208. DOI: 10.1016/0031-0182(93)90012-8.

Cohen KM, Gibbard PL. 2012. Regional chronostratigraphical correlation chart for the last 270,000 years: Europe north of the Mediterranean. Quaternary International 279: 93.

Corander J, Marttinen P. 2006. Bayesian identification of admixture events using multilocus molecular markers. Molecular Ecology 15: 2833-2843. DOI: 10.1111/j.1365294X.2006.02994.x 
Darriba D, Taboada GL, Doallo R, Posada D. 2012. jModelTest 2: more models, new heuristics and parallel computing. Nature Methods 9: 772-772. DOI: 10.1038/nmeth.2109. Drummond AJ, Rambaut A. 2007. BEAST: Bayesian evolutionary analysis by sampling trees. BMC Evolutionary Biology 7: 214. DOI: 10.1186/1471-2148-7-214.

Durka W, Babik W, Ducroz JF, Heidecke D, Rosell F, Samjaa R, Saveljev AP, Stubbe A, Ulevicius A, Stubbe M, P. Saveljev A, Ulevičius A. 2005. Mitochondrial phylogeography of the Eurasian beaver Castor fiber L. Molecular Ecology 14: 3843-3856. DOI: 10.1111/j.1365294X.2005.02704.x.

Earl DA, von Holdt BM. 2012. STRUCTURE HARVESTER: a website and program for visualizing STRUCTURE output and implementing the Evanno method. Conservation Genetics Resources 4: 359-361. DOI: 10.1007/s12686-011-9548-7.

Evanno G, Regnaut S, Goudet J. 2005. Detecting the number of clusters of individuals using the software STRUCTURE: A simulation study. Molecular Ecology 14: 2611-2620. DOI: 10.1111/j.1365-294X.2005.02553.x.

Excoffier L, Lischer HEL. 2010. Arlequin suite ver 3.5: A new series of programs to perform population genetics analyses under Linux and Windows. Molecular Ecology Resources 10: 564-567. DOI: 10.1111/j.1755-0998.2010.02847.x.

Goudet J. 2001. FSTAT, a program to estimate and test gene diversities and fixation indices (Version 2.9.3). Available at http://www2.unil.ch/popgen/softwares/fstat.htm (assessed 22 March 2015).

Guindon S, Gascuel O. 2003. A simple, fast, and accurate algorithm to estimate large phylogenies by maximum likelihood. Systematic Biology 52: 696-704. DOI: 10.1080/10635150390235520. 
Haffer J. 1969. Speciation in Amazonian Forest Birds. Science 165: 131-137.

Hijmans RJ, Cameron SE, Parra JL, Jones PG, Jarvis A. 2005. Very high resolution interpolated climate surfaces for global land areas. International Journal of Climatology 25: 1965-1978. DOI: 10.1002/joc.1276.

Hijmans R., van Etten J. 2015. raster: Geographic Data Analysis and Modeling. R package version 2.3-40.

Hipsley CA, Müller J. 2014. Beyond fossil calibrations: realities of molecular clock practices in evolutionary biology. Frontiers in Genetics 5: 138. DOI: 10.3389/fgene.2014.00138. Hubisz MJ, Falush D, Stephens M, Pritchard JK. 2009. Inferring weak population structure with the assistance of sample group information. Molecular Ecology Resources 9:1322-1332. DOI: 10.1111/j.1755-0998.2009.02591.x Igea J, Aymerich P, Fernández-González A, González-Esteban J, Gómez A, Alonso R, Gosálbez J, Castresana J. 2013. Phylogeography and postglacial expansion of the endangered semi-aquatic mammal Galemys pyrenaicus. BMC Evolutionary Biology 13: 115. DOI: 10.1186/1471-2148-13-115.

Kopelman NM, Mayzel J, Jakobsson M, Rosenberg NA, Mayrose I. 2015. Clumpak: a program for identifying clustering modes and packaging population structure inferences across K. Molecular Ecology Resources 15: 1179-1191. DOI: 10.1111/1755-0998.12387.

Lambeck K, Esat TM, Potter EK. 2002. Links between climate and sea levels for the past three million years. Nature 419: 199-206. DOI: 10.1038/nature01089.

Laurence S, Smith MJ, Schulte-Hostedde AI. 2013. Effects of structural connectivity on fine scale population genetic structure of muskrat, Ondatra zibethicus. Ecology and Evolution 3: 3524-35. DOI: 10.1002/ece3.741. 
604 605 606 607 608 609 610 611 612 613 614 615 616 617 618 619 620 621 622 623 624 625 626

Leite YLR, Costa LP, Loss AC, Rocha RG, Batalha-Filho H, Bastos AC, Quaresma VS, Fagundes V, Paresque R, Passamani M, Pardini R. 2016. Neotropical forest expansion during the last glacial period challenges refuge hypothesis. Proceedings of the National Academy of Sciences 113: 1008-1013. DOI: 10.1073/pnas.1513062113.

Leite YLR, Kok PJR, Weksler M. 2015. Evolutionary affinities of the 'Lost World' mouse suggest a late Pliocene connection between the Guiana and Brazilian shields. Journal of Biogeography 42: 706-715. DOI: 10.1111/jbi.12461.

$$
\text { Leite RN, Rogers DS. 2013. Revisiting Amazonian phylogeography: insights into }
$$

diversification hypotheses and novel perspectives. Organisms Diversity \& Evolution 13: 639664. DOI: $10.1007 / \mathrm{s} 13127-013-0140-8$.

Librado P, Rozas J. 2009. DnaSP v5: A software for comprehensive analysis of DNA polymorphism data. Bioinformatics 25: 1451-1452. DOI: 10.1093/bioinformatics/btp187. Lima DO, Pinho GM, Fernandez FAS. 2016. Spatial patterns of the semi-aquatic rodent Nectomys squamipes in Atlantic forest streams. Journal of Natural History 50: 497-511. DOI: 10.1080/00222933.2015.1059516.

Machado LF, Leite YLR, Christoff AU, Giugliano LG. 2014. Phylogeny and biogeography of tetralophodont rodents of the tribe Oryzomyini (Cricetidae: Sigmodontinae). Zoologica Scripta 43: 119-130. DOI: 10.1111/zsc.12041.

Maroja LS, Almeida FC, Seuánez HN. 2003. Genetic differentiation in geographically close populations of the water rat Nectomys squamipes (Rodentia, Sigmodontinae) from the Brazilian Atlantic Forest. Genetics and Molecular Biology 26: 403-410. DOI: 10.1590/S141547572003000400002 .

Maroja LS, Almeida FC, Cerqueira R, Seuánez HN, Moreira MAM. 2003. Nectomys 
627 squamipes microsatellites and homologous loci in sigmodontine rodents. Journal of Heredity 94:

628 171-174. DOI: 10.1093/jhered/esg017

629

630

631

632

633

634

635

636

637

638

639

640

641

642

643

644

645

646

647

648

649

Matschiner M, Salzburger W. 2009. TANDEM: integrating automated allele binning into genetics and genomics workflows. Bioinformatics 25: 1982-3. DOI:

10.1093/bioinformatics/btp303.

Muscarella R, Galante PJ, Soley-Guardia M, Boria RA, Kass JM, Uriarte M, Anderson RP. 2014. ENMeval: An R package for conducting spatially independent evaluations and estimating optimal model complexity for Maxent ecological niche models. Methods in Ecology and Evolution 5: 1198-1205. DOI: 10.1111/2041-210X.12261.

Naxara L. 2008. Importância dos corredores ripários para a fauna - pequenos mamíferos em manchas de floresta, matriz do entorno e elementos lineares em uma paisagem fragmentada de Mata Atlântica. Unpublished thesis, Universidade de São Paulo. DOI:

10.11606/D.41.2008.tde-15122008-102749.

Oksanen J, Blanchet FG, Kindt R, Legendre P, Minchin PR, O’Hara RB, Simpson GL, Solymos P, Stevens MHH, Wagner H. 2015. vegan: Community Ecology Package. $R$ package version 2.2-1: 264.

Otto-Bliesner BL, Marshall SJ, Overpeck JT, Miller GH, Hu A. 2006. Simulating arctic climate warmth and icefield retreat in the last interglaciation. Science 311: 1751-1753. DOI: 10.1126/science. 1120808 .

Palma RE, Rodríguez-Serrano E, Rivera-Milla E, Hernandez CE, Salazar-Bravo J, Carma MI, Belmar-Lucero S, Gutierrez-Tapia P, Zeballos H, Yates TL. 2010. Phylogenetic relationships of the pygmy rice rats of the genus Oligoryzomys Bangs, 1900 (Rodentia: Sigmodontinae). Zoological Journal of the Linnean Society 160: 551-566. DOI: 10.1111/j.1096- 
3642.2009.00621.x.

Pereira TL, Santos U, Schaefer CE, Souza GO, Paiva SR, Malabarba LR, Schmidt EE, Dergam JA. 2013. Dispersal and vicariance of Hoplias malabaricus (Bloch, 1794) (Teleostei, Erythrinidae) populations of the Brazilian continental margin (L Rocha, Ed.). Journal of Biogeography 40: 905-914. DOI: 10.1111/jbi.12044.

Pérez-Alquicira J, Weller SG, Domínguez CA, Molina-Freaner FE, Tsyusko OV. 2018. Different patterns of colonization of Oxalis alpina in the Sky Islands of the Sonoran desert via pollen and seed flow. Ecology and Evolution. In Press. DOI: 10.1002/ece3.4096.

Phillips SJ, Anderson RP, Schapire RE. 2006. Maximum entropy modeling of species geographic distributions. Ecological Modelling 190: 231-259. DOI:

10.1016/j.ecolmodel.2005.03.026.

Pires AS, Lira PK, Fernandez FAS, Schittini GM, Oliveira LC. 2002. Frequency of movements of small mammals among Atlantic Coastal Forest fragments in Brazil. Biological Conservation 108: 229-237. DOI: 10.1016/S0006-3207(02)00109-X.

Piry S, Luikart G, Cornuet JM. 1999. BOTTLENECK: a computer program for detecting recent reductions in the effective size using allele frequency data. Journal of Heredity 90: 502503.

Pritchard JK, Stephens M, Donnelly P. 2000. Inference of population structure using multilocus genotype data. Genetics 155: 945-959.

Pritchard JK, Wen X, Falush D. 2010. Documentation for STRUCTURE software: Version 2.3. Available in:

http://web.stanford.edu/group/pritchardlab/software/structure_v.2.3.1/documentation.pdf Putman AI, Carbone I. 2014. Challenges in analysis and interpretation of microsatellite 
673 674 675 676

data for population genetic studies. Ecology and Evolution 4: 4399-4428.

Quaglietta L, Fonseca VC, Hájková P, Mira A, Boitani L. 2013. Fine-scale population genetic structure and short-range sex-biased dispersal in a solitary carnivore, Lutra lutra. Journal of Mammalogy 94: 561-571. DOI: 10.1644/12-MAMM-A-171.1.

Rabineau M, Berné S, Olivet JL, Aslanian D, Guillocheau F, Joseph P. 2006. Paleo sea levels reconsidered from direct observation of paleoshoreline position during Glacial Maxima (for the last 500,000 yr). Earth and Planetary Science Letters 252: 119-137. DOI: 10.1016/j.epsl.2006.09.033.

Raes N, Cannon CH, Hijmans RJ, Piessens T, Saw LG, van Welzen PC, Slik JWF. 2014. Historical distribution of Sundaland's Dipterocarp rainforests at Quaternary glacial maxima. Proceedings of the National Academy of Sciences of the United States of America 111: 16790-5. Rambaut A, Suchard MA, Xie D, Drummond AJ. 2014. Tracer v.1.6. Available at http://beast.bio.ed.ac.uk/Tracer (accessed 22 March 2015).

Ribeiro AC. 2006. Tectonic history and the biogeography of the freshwater fishes from the coastal drainages of eastern Brazil an example of faunal evolution associated with a divergent continental margin. Neotroprical Ichthyology 4: 225-246. DOI: 10.1590/S167962252006000200009.

Ronquist F, Teslenko M, van der Mark P, Ayres DL, Darling A, Höhna S, Larget B, Liu L, Suchard MA, Huelsenbeck JP. 2012. MrBayes 3.2: efficient Bayesian phylogenetic inference and model choice across a large model space. Systematic Biology 61: 539-42. DOI: 10.1093/sysbio/sys029.

Rousset F. 2008. Genepop'007: a complete re-implementation of the genepop software for Windows and Linux. Molecular Ecology Resources 8: 103-6. DOI: 10.1111/j.1471- 
8286.2007.01931.x.

Saadi A, Machette MN, Haller KM, Dart RL, Bradley LA, Souza AMPD. 2002. Map and database of Quaternary faults and lineaments in Brazil. USGS OpenFile Report 02-230: 59.

Tamura K, Peterson D, Peterson N, Stecher G, Nei M, Kumar S. 2011. MEGA5: molecular evolutionary genetics analysis using maximum likelihood, evolutionary distance, and maximum parsimony methods. Molecular Biology and Evolution 28: 2731-2739. DOI: 10.1093/molbev/msr121.

Thomaz AT, Malabarba LR, Bonatto SL, Knowles LL. 2015. Testing the effect of palaeodrainages versus habitat stability on genetic divergence in riverine systems: study of a Neotropical fish of the Brazilian coastal Atlantic Forest. Journal of Biogeography 42: 23892401. DOI: $10.1111 /$ jbi.12597.

Thomé MTC, Zamudio KR, Haddad CFB, Alexandrino J. 2014. Barriers, rather than refugia, underlie the origin of diversity in toads endemic to the Brazilian Atlantic Forest. Molecular Ecology 23: 6152-6164. DOI: 10.1111/mec.12986.

Valdez L, D’Elía G. 2013. Differentiation in the Atlantic Forest: phylogeography of Akodon montensis (Rodentia, Sigmodontinae) and the Carnaval-Moritz model of Pleistocene refugia. Journal of Mammalogy 94: 911-922. DOI: 10.1644/12-MAMM-A-227.1.

Vanzolini P, Williams EE. 1970. South American anoles: geographic differentiation and evolution of the Anolis chrysolepis species group (Sauria, Iguanidae). Arquivos de Zoologia (São Paulo) 19: 1-298.

Villamor A, Costantini F, Abbiati M. 2018. Multilocus phylogeography of Patella caerulea (Linnaeus, 1758) reveals contrasting connectivity patterns across the Eastern-Western Mediterranean transition. Journal of Biogeography. In Press. DOI: 10.1111/jbi.13232. 
Wang X, Sun X, Wang P, Stattegger K. 2009. Vegetation on the Sunda Shelf, South China 720 Sea, during the Last Glacial Maximum. Palaeogeography, Palaeoclimatology, Palaeoecology 721 278: 88-97. DOI: 10.1016/j.palaeo.2009.04.008.

722 Watanabe S, Hajima T, Sudo K, Nagashima T, Takemura T, Okajima H, Nozawa T,

723 724 725 726 727 728

Kawase H, Abe M, Yokohata T, Ise T, Sato H, Kato E, Takata K, Emori S, Kawamiya M. 2011.

MIROC-ESM 2010: model description and basic results of CMIP5-20c3m experiments.

Geoscientific Model Development 4: 845-872. DOI: 10.5194/gmdd-4-1063-2011.

Weir BS, Cockerham CC. 1984. Estimating F-Statistics for the analysis of population structure. Evolution 38: 1358-1370. DOI: 10.1111/j.1558-5646.1984.tb05657.x.

Weitzman SH, Menezes NA, Weitzman MJ. 1988. Phylogenetic biogeographyof the Glandulocaudini (Teleostei: Characiformes, Characidae) with comments on the distributions of other freshwater fishes in eastern and southeastern Brazil. In: Vanzolini PE, Heyer WR, eds. Proceedings of a Workshop on Neotropical Distribution Patterns. Rio de Janeiro, RJ: Academia Brasileira de Ciências, 379-427.

Zheng C, Yang F, Zeng L, Vargo EL, Xu Y. 2018. Genetic diversity and colony structure of Tapinoma melanocephalum on the islands and mainland of South China. Ecology and Evolution. In Press. DOI: 10.1002/ece3.4065. 


\section{Table $\mathbf{1}$ (on next page)}

Analysis of molecular variance (AMOVA) for Nectomys squamipes considering river basins, localities, and the genetic markers.

Percentage of genetic variation, fixation indices and p-values attributable to heterogeneity among river basins, among localities within same basin, among localities and among individuals are presented in each line. 


\begin{tabular}{|c|c|c|c|c|c|c|c|}
\hline Markers & $\begin{array}{l}\text { Source of } \\
\text { Variation }\end{array}$ & d.f. & $\begin{array}{l}\text { Sum of } \\
\text { Squares }\end{array}$ & $\begin{array}{c}\text { Variance } \\
\text { Components }\end{array}$ & $\begin{array}{c}\text { Variation } \\
(\%)\end{array}$ & $\begin{array}{l}\text { Fixation } \\
\text { Indices }\end{array}$ & $p$-value \\
\hline \multirow{4}{*}{ Cyt b } & Among Basins & 4 & 7.13 & 0.05 & 11.08 & $\mathrm{~F}_{\mathrm{CT}}: 0.11$ & 0.03 \\
\hline & $\begin{array}{l}\text { Among Localities } \\
\text { within Basins }\end{array}$ & 15 & 14.97 & 0.21 & 42.54 & $\mathrm{~F}_{\mathrm{SC}}: 0.48$ & $<0.01$ \\
\hline & Within Localities & 56 & 12.96 & 0.23 & 46.38 & $\mathrm{~F}_{\mathrm{ST}}: 0.54$ & $<0.01$ \\
\hline & Total & 75 & 35.05 & 0.5 & & & \\
\hline \multirow{4}{*}{ D-loop } & Among Basins & 4 & 6.47 & $<0.01$ & 1.19 & $\mathrm{~F}_{\mathrm{CT}}: 0.01$ & 0.32 \\
\hline & $\begin{array}{l}\text { Among Localities } \\
\text { within Basins }\end{array}$ & 22 & 26.88 & 0.18 & 35.55 & $\mathrm{~F}_{\mathrm{SC}}: 0.36$ & $<0.01$ \\
\hline & Within Localities & 121 & 38.29 & 0.32 & 63.26 & $\mathrm{~F}_{\mathrm{ST}}: 0.37$ & $<0.01$ \\
\hline & Total & 147 & 71.65 & 0.5 & & & \\
\hline \multirow{4}{*}{ MS (all loci) } & Among Basins & 4 & 2665.46 & 2.62 & 1 & $\mathrm{~F}_{\mathrm{CT}}: 0.01$ & 0.24 \\
\hline & $\begin{array}{l}\text { Among Localities } \\
\text { within Basins }\end{array}$ & 21 & 10181.53 & 30.09 & 11.49 & $\mathrm{~F}_{\mathrm{SC}}: 0.12$ & 0.02 \\
\hline & Within Localities & 212 & 48574.63 & 229.13 & 87.5 & $\mathrm{~F}_{\mathrm{ST}}: 0.12$ & $<0.01$ \\
\hline & Total & 237 & 61421.62 & 261.84 & & & \\
\hline
\end{tabular}

1 d.f. = degrees of freedom;

$2 \mathrm{MS}=$ Microsatellite. 
Figure 1

Geographic distribution of the Nectomys squamipes samples.

The colors represent the basins with main rivers. Numbers correspond to localities in Appendix S1.

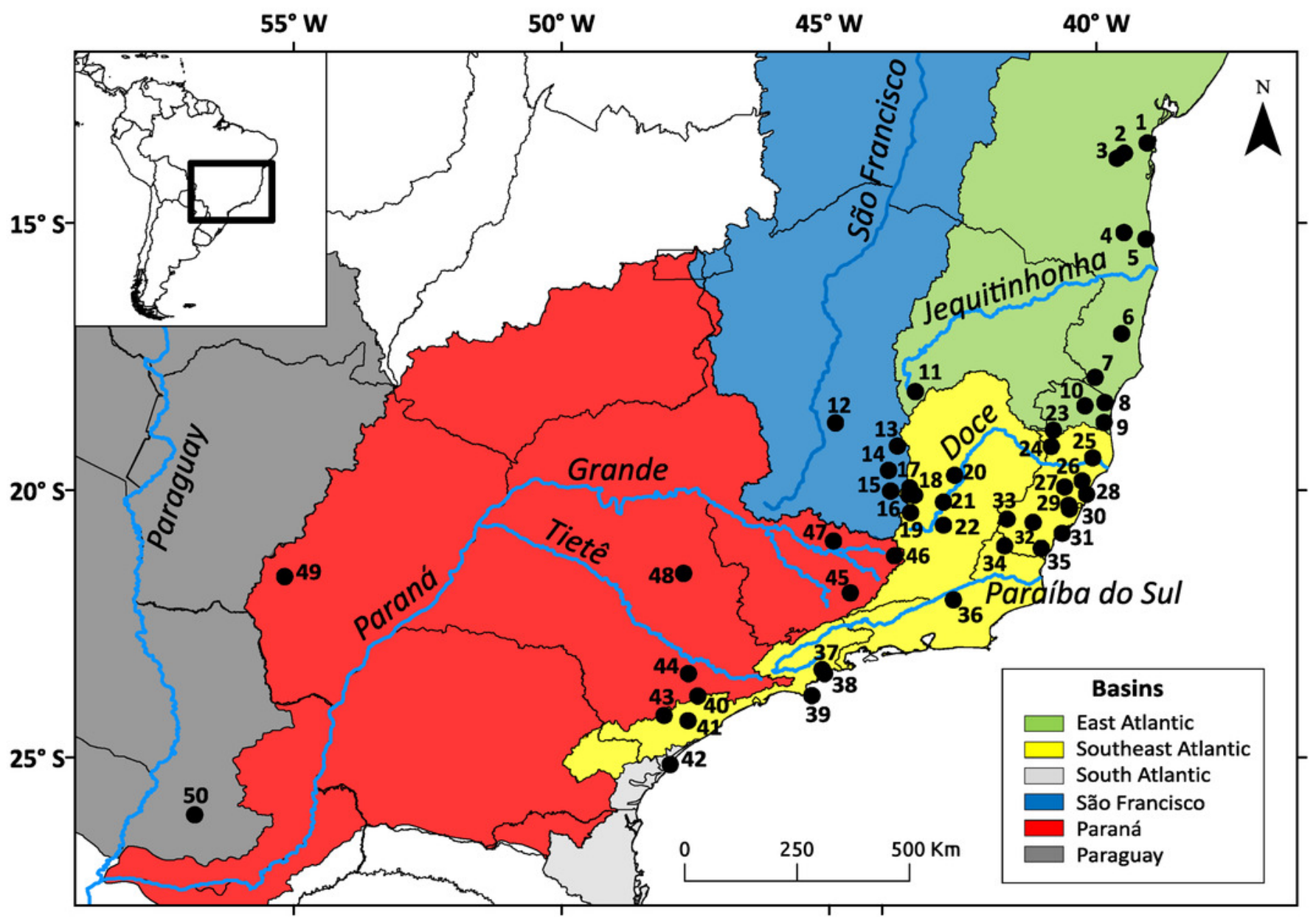




\section{Figure 2}

Phylogeny through Bayesian inference (BI) for Cyt b samples.

Main clades for Nectomys squamipes are represented with white circles, and their bootstrap support for maximum parsimony (MP), maximum likelihood (ML), and the posterior probability for bayesian inference (BI) are also shown in the following order: MP/ML/IB. The topology of those main clades did not change in the different phylogenetics methods, only the statistical support. We chose the BI tree because it presented higher values of statistical support. Numbers correspond to localities in Appendix S1 and Fig. 1. The circle colors indicate the river basin where samples occur. 


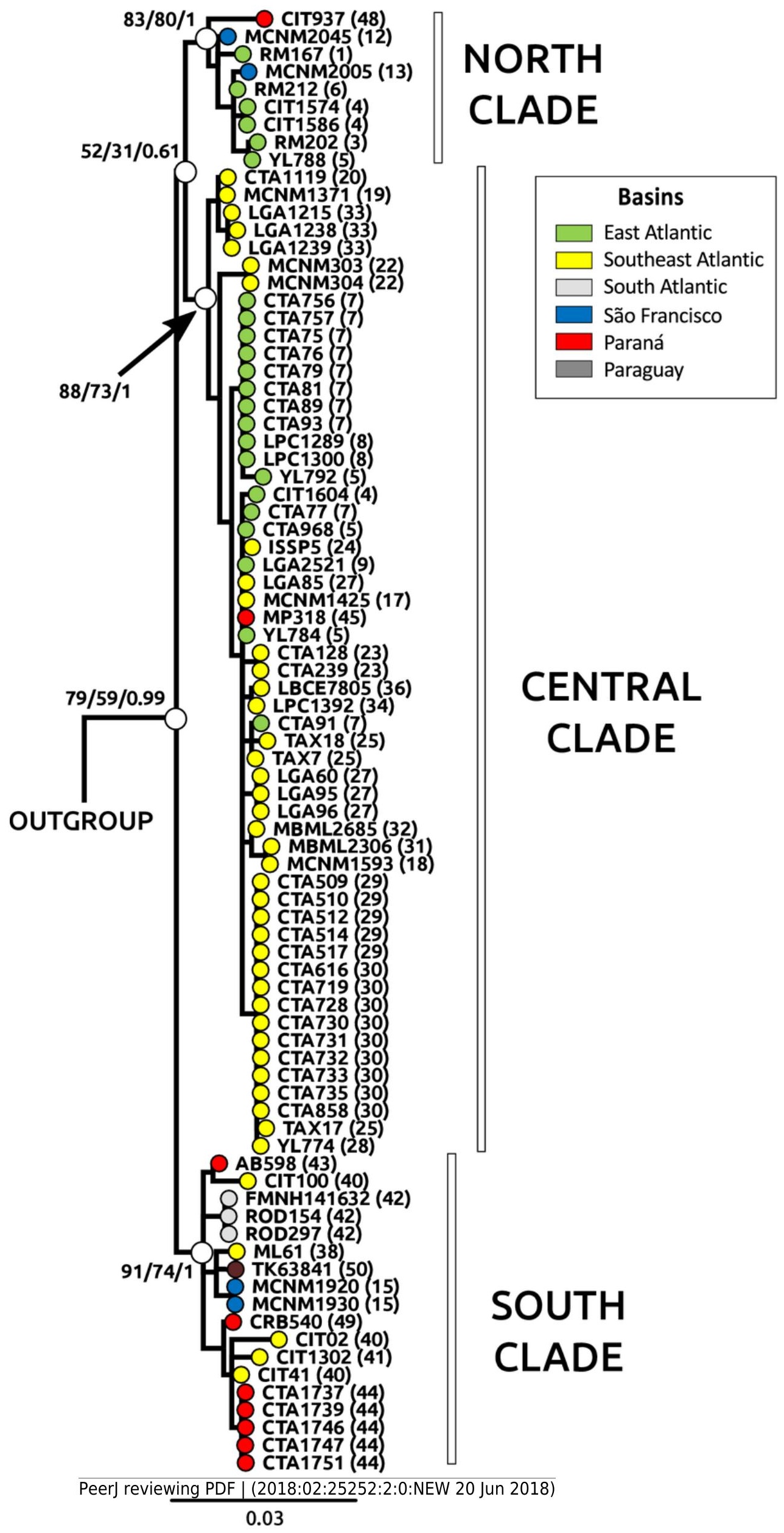




\section{Figure 3}

Bar graphs for genetic structure in Nectomys squamipes using Cyt b (A), and D-loop (B) sequences in BAPS, and microsatellite data (C) in STRUCTURE.

Each bar represents an individual organized by river basin and by latitude inside each basin. Black lines represent the basins limits, and each different colour a cluster, 3 for Cyt b, 6 for D-loop, and 4 for microsatellite data. Yellow represents the clusters related to Central clade in all markers, green to North clade, and red to South clade. Other colours were chose to improving the contrast. Numbers below bars correspond to localities in Appendix S1 and Fig. 1.

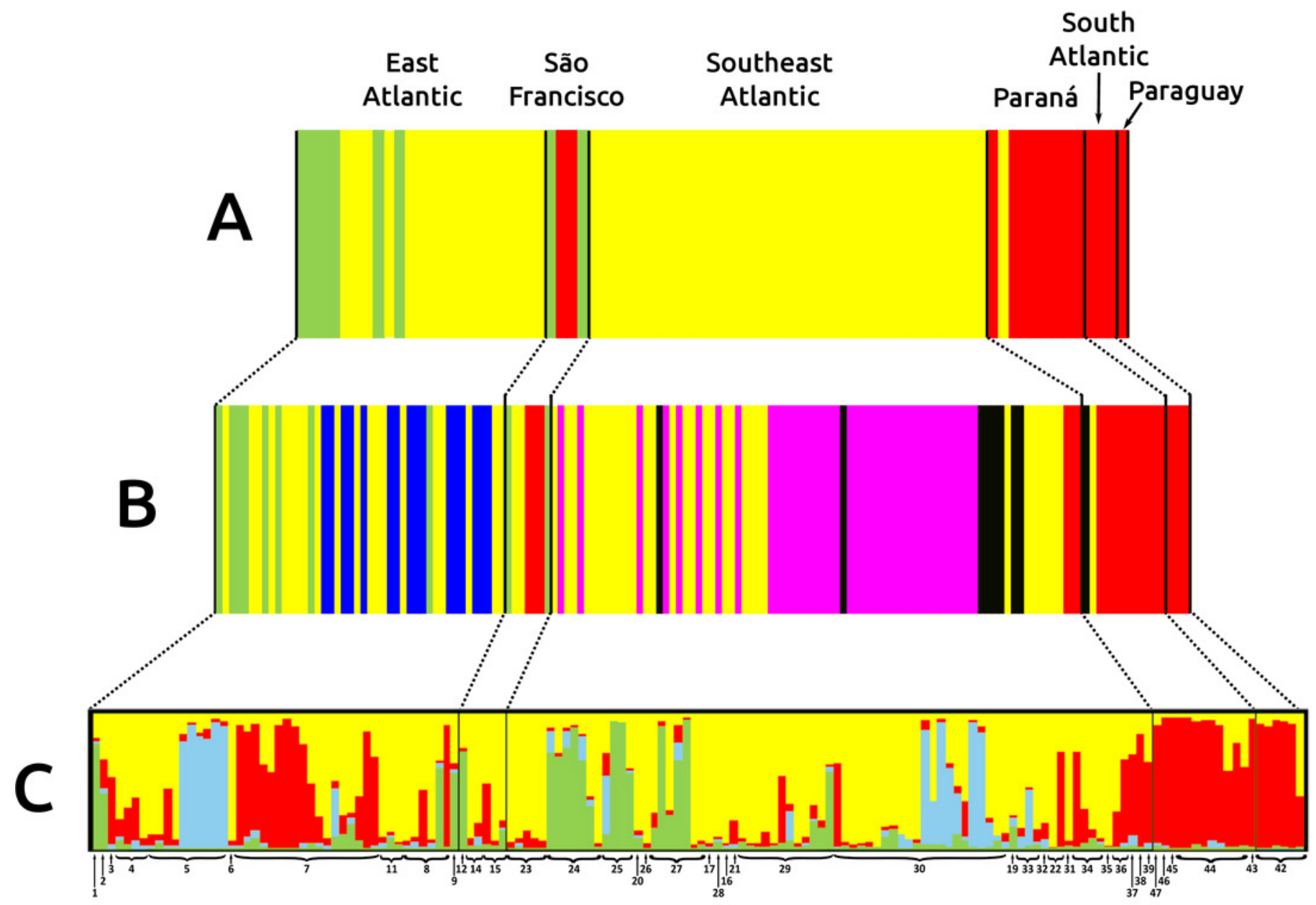




\section{Figure 4}

Relaxed clock tree based on the Cyt b sequences of Nectomys.

Bars represent the confidence interval (95\%). The exact mean values and confidence intervals are in Table S2.8. Localities numbers in parentheses are the same that Fig. 1, and they refer to Appendix S1, and the haplotype list are in the Table S2.3. The circle colours indicate the river basin where haplotypes occur. $\mathrm{Ma}=$ millions years ago . 


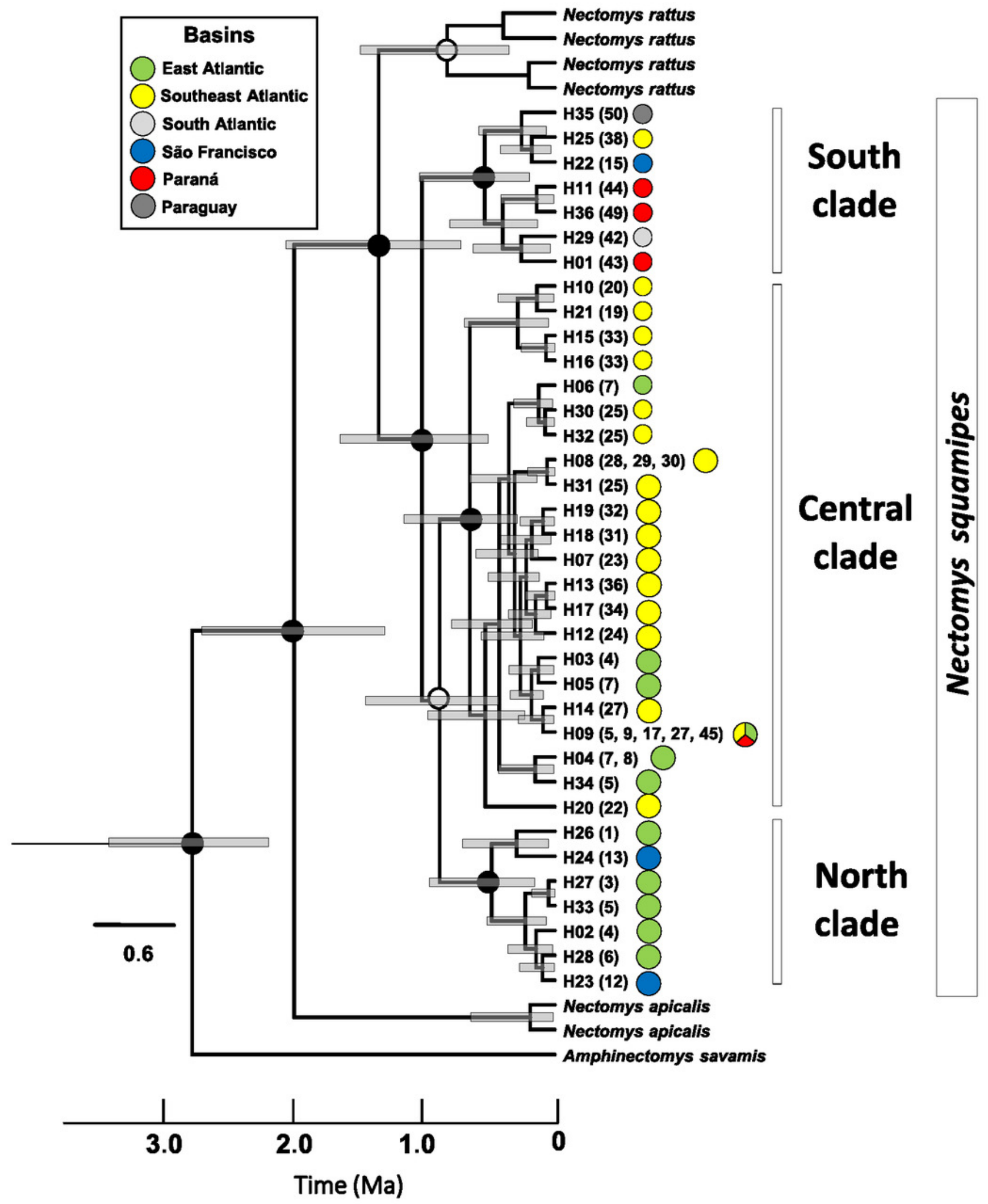


Figure 5

Skyline plot showing the effective population size $\left(\mathrm{N}_{\mathrm{e}}\right)$ of Nectomys squamipes.

The continuous black line is the effective population size $x$ Generation Time $\left(\mathrm{N}_{\mathrm{e}}\right)$ based on Cyt b sequences (with the $95 \%$ confidence interval in pointed line). We compared to the level of the stable isotope $\delta^{18} \mathrm{O}_{\text {ocean }} \%$ (Cohen \& Gibbard, 2012), corresponding to temperature oscillation (red line). The arrows indicate the period of the last glacial maximum (LGM) and the last interglacial (LIG). $k a=$ thousands of years ago.

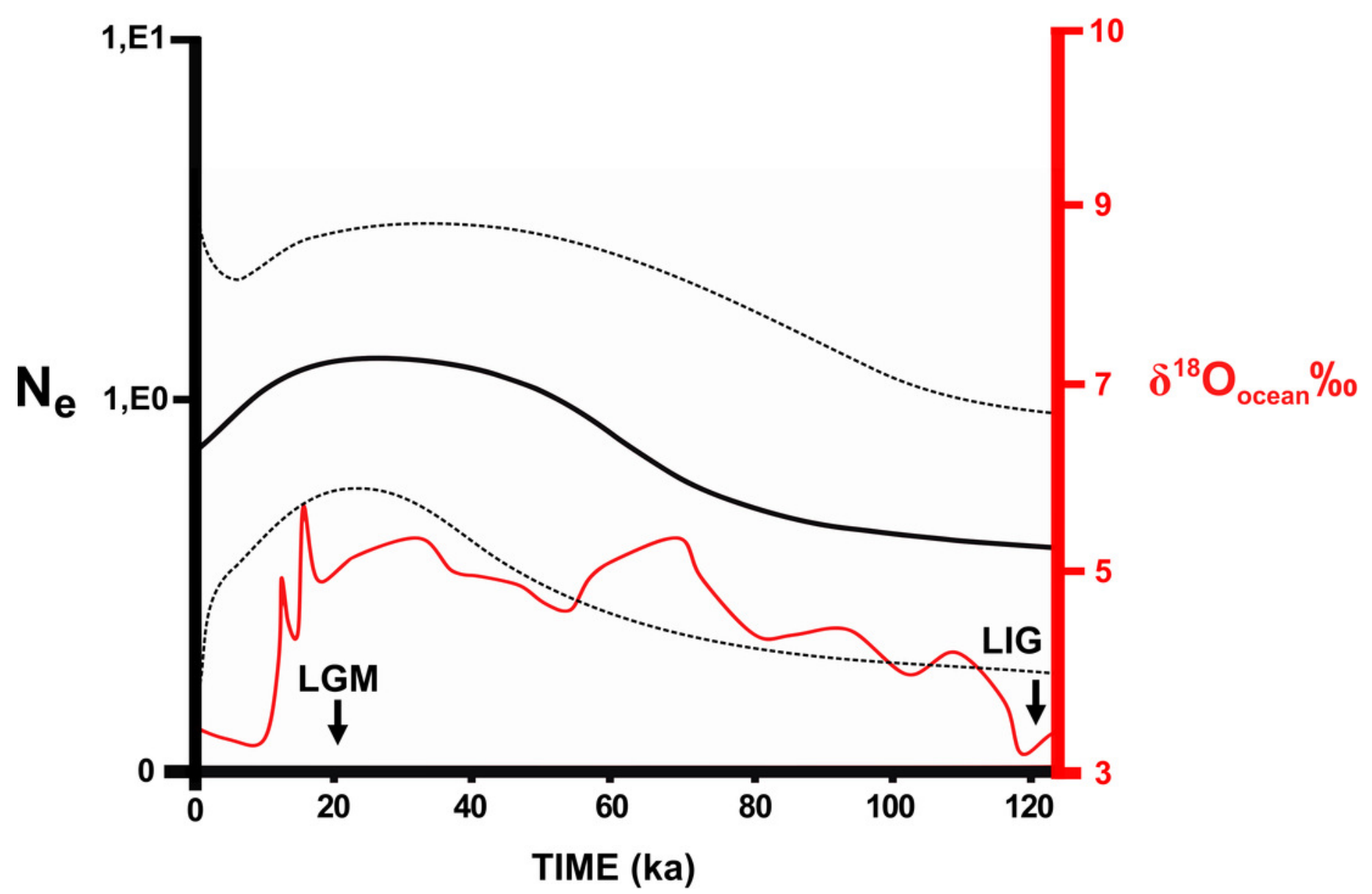


Figure 6

Species distribution models for the river basins where N. squamipes occurs.

Dots represent the points used in building the model, and the square the points used in external validation. A: present; B: LGM = Last Glacial Maximum (22 ka); C: LIG = Last Interglacial (120-140 ka). $\mathrm{ka}=$ thousands of years ago.
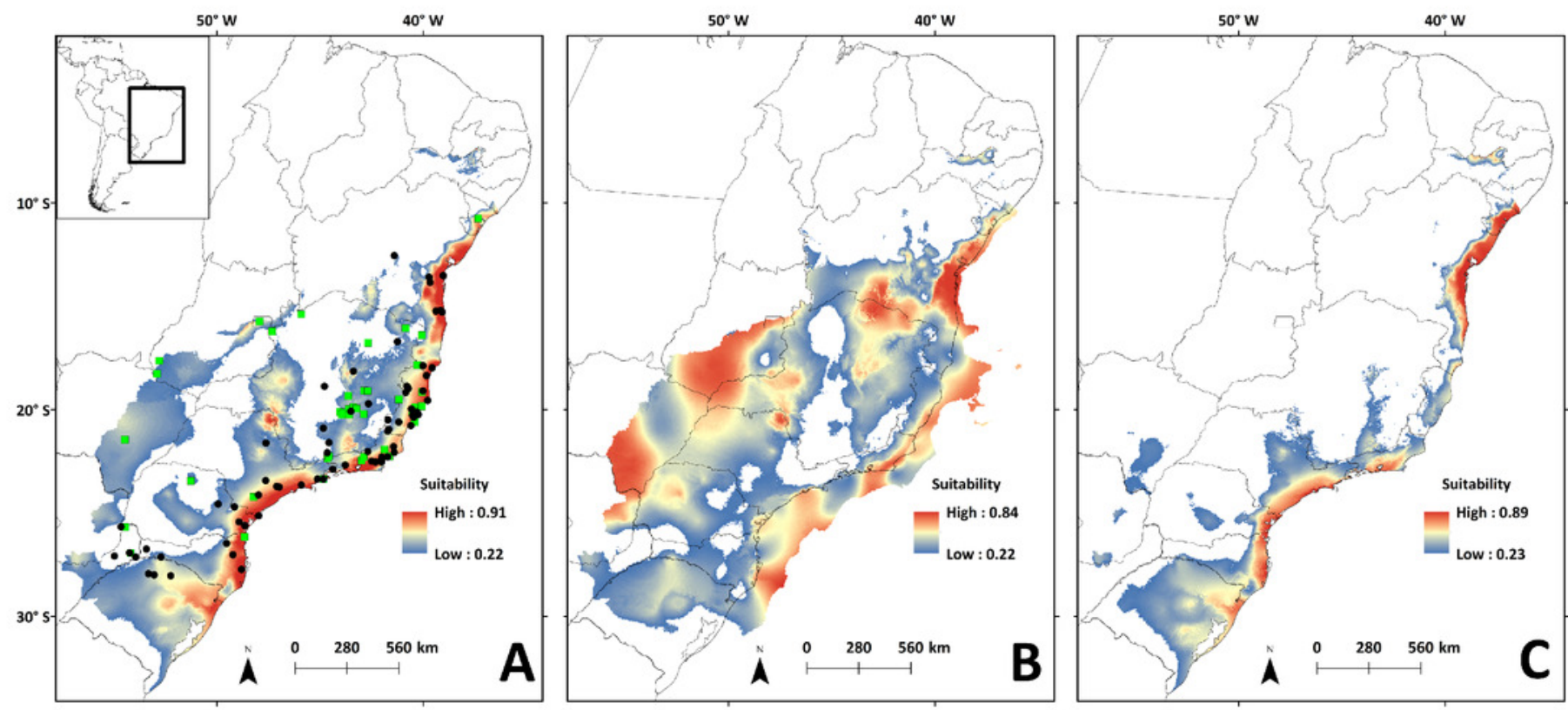
Figure 7

Probability of gene flow paths for Nectomys squamipes.

Connections among localities with shared Cyt $b(A$ and $D)$, and D-loop ( $B$ and $E$ ) haplotypes, and same allele size for all microsatellite loci ( $\mathrm{C}$ and $\mathrm{F}$ ). The gene flow paths were built using the SDM for the LGM as a friction layer (A-C), and the present-day model (D-F). Dotted line indicates the continental shelf exposed during the LGM, and submerged in the present-day.
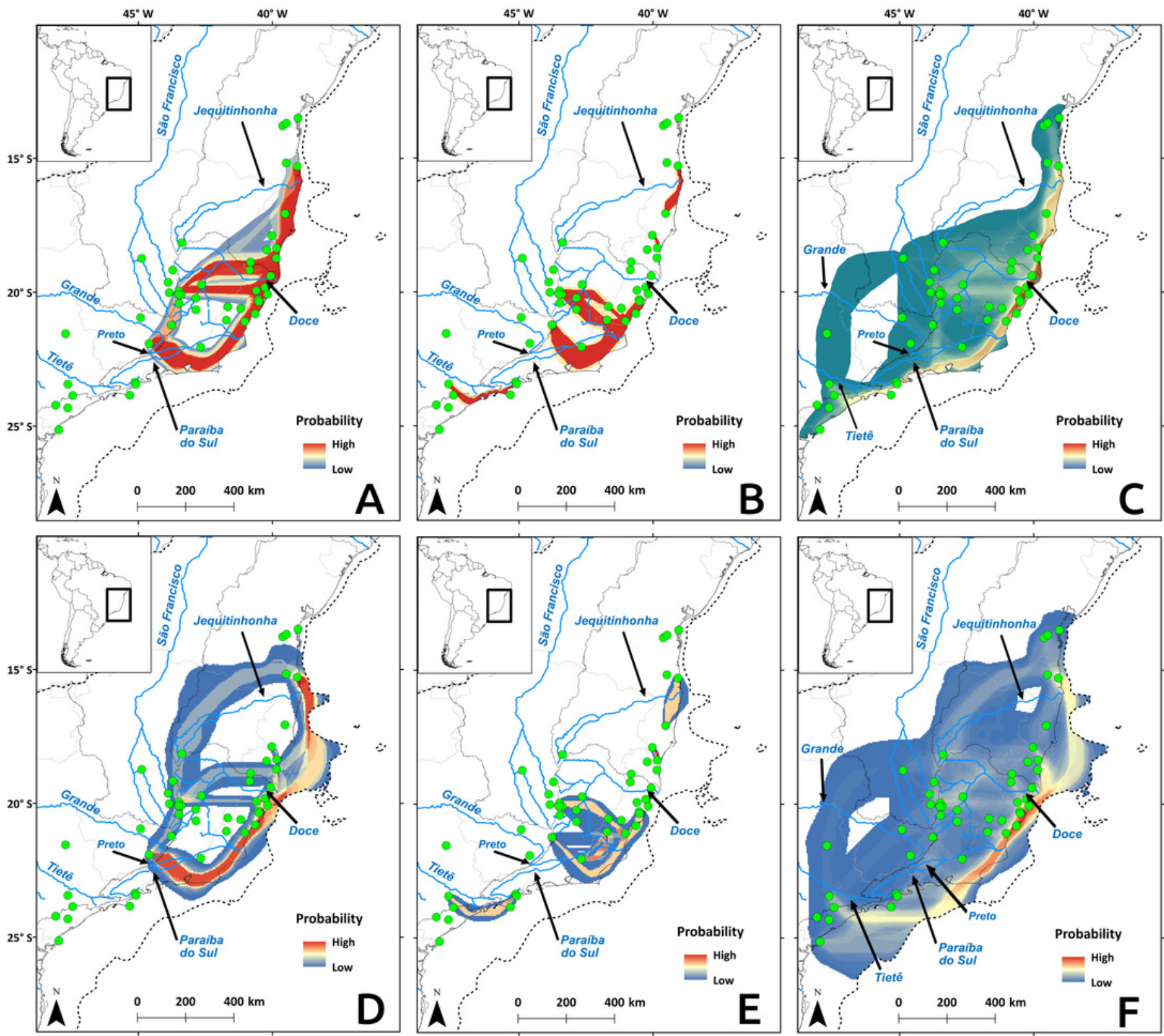